\title{
A arte nas ruas da cidade: estratégia de ressignificação e de interação comunicacional
}

\author{
Ione Maria Ghislene Bentz \\ Doutora; Universidade do Vale do Rio dos Sinos \\ ioneb@unisinos.br
}

\section{Resumo}

O texto investiga os efeitos das retóricas visuais na composição de metáforas/alegorias urbanas, através da produção de significados simbólicos e das relações de comunicação mediadas pelas tecnologias urbanas. Esses artefatos estão de tal modo presentes no cotidiano, que se tornaram próteses no corpo da cidade. Foram escolhidas temáticas e práticas contemporâneas, representantes de formas de natureza no espaço urbano, que produzem um diálogo com a cultura sob a forma de narrativas. A matriz narrativa trabalha: (a) o elemento lúdico, presente nas diversas formas de manifestação; e (b) o elemento de crítica social, presente nos argumentos narrativos dos textos em análise. O desenvolvimento do tema obedece aos parâmetros das teorias da linguagem, da compreensão da semiose e da interação comunicacional. Objetiva-se identificar e compreender os efeitos dos sentidos e as formas de interação, ambos mediados, em semioses complexas, por dispositivos urbanos.

\section{Palavras-chave}

Artefatos. Cidades. Ambientes. Narrativas. Metáforas.

\section{Introdução}

A rua como espaço público é lugar de registros, suportes, exposições e mobiliários que atuam como veículos de políticas culturais geradoras de novas experiências estéticas de sentido e de comunicação. As expressões culturais ganham as ruas e transformam os lugares de tal modo, que tornam-se capazes de formar desde grandes redes de cartões postais até espetáculos de registro patrimonial histórico. De certa forma, trata-se da própria história reescrevendo, de modo ficcional, o seu passado e projetando o seu futuro. De imediato, uma controvérsia se apresenta no que tange a compreensão do significado de arte urbana, termo este que se refere, não apenas a arte expressa nas paredes, muros ou espaços fixos externos, 
mas também a arte que vai das ruas para exposições, mostras ou instalações. 0 que ganha relevância, portanto, não é apenas o artefato em si, mas o seu entorno; a concepção das cenas, protagonizadas pelos enunciados-objeto (FONTANILLE, 2005). Libertadas as produções artísticas de seus espaços tradicionais, elas vão às ruas para encontrar as pessoas e favorecer, de modo democrático, tanto a fruição estética em si, quanto à veiculação de mensagens de cunho político, religioso ou mesmo comercial.

Historicamente, a arte se apresenta diante da sociedade como um espaço poético de múltiplas funções e de expressão livre. Com a chegada do pensamento dos formalistas (T0DOROV, 2003) e com o desenvolvimento e divulgação das teses estruturais (JAKOBSON, 2001), espaço ainda maior é conferido a essa forma de expressão cultural. Trata-se de um movimento de múltiplas pautas, entre as quais se destaca a natureza autônoma da linguagem poética, definida como um conjunto de propriedades características dessa linguagem, e expressa pelos conceitos de literalidade ou artisticidade. 0 potencial dos signos de "significar outra coisa que não eles" estimula a explosão de significados simbólicos. Embora esse tipo de compreensão pareça dessacralizar a arte, não é inegável seu papel na produção de certa desconstrução do seu conceito clássico, com efeitos de renovação e atualização. Tendo como próximo passo a inserção desta arte nas ruas, promove-se assim a ampliação de sua abrangência, conforme possibilita a popularização da experiência estética, traçando roteiros que integram praças, ruas, muros e largos, e, graças à mobilidade urbana, renovando trajetos e cenários. Contempla, assim, todas as classes sociais, passando a dispensar a necessidade de um espaço ou ritual específico para sua realização como leitura e como fruição. Linguagens produzem jogos que não dependem de referências à realidade, mas que se reconhecem entre si e ganham vida própria. Essa autonomia replica na pluralidade dos textos (BARTHES, 2008), em diálogo entre eles e com os leitores.

\section{A construção dos significados: suportes e artefatos}

Se as produções estéticas estão expostas em outros espaços, suportes e leituras, como se dá essa fruição? Qual a relevância desses elementos de entorno na configuração dos textos-enunciados? 0 texto-enunciado tem um nível de pertinência semiótica que o estatui como um conjunto expressivo de significantes que opera por comutação, segmentação e catálises, responsáveis pela produção de significados e pela agregação de valor. Tais enunciados produzem uma dimensão plástica e imagética, e a troca que se dá entre esses actantes, pessoas e obras, considera os objetos-suporte em que esses textos estão inscritos, pois eles 
compõem a cena em nível de expressão. Realizam-se duas instâncias significativas: a dimensão predicativa e a estratégica. Reconhecem-se, portanto, artistas e públicos como participantes de um metaprojeto que, em um segundo momento, reinaugura as obras e as ressignifica. Deste modo, as isotopias (GREIMAS, 1973), fios semânticos que redundam nas estruturas textuais, passam a construir-se a cada tempo e leitura.

Duas formas sob as quais a arte na rua pode apresentar-se são: ao longo das avenidas e pelas calçadas, tendo como contexto a paisagem urbana in natura (Figura 1), ou ainda, sobre os muros da cidade (Figura 2). Na primeira figura, as peças estão postas como em exposição, como artefatos móveis que são; já na segunda, a arte constitui a pele da cidade, isto é, uma pele que se sobrepõe outra pré-existente que, devido a sua imobilidade, mesclam-se sobre a superfície das edificações urbanas. A reescrição contemporânea, contudo, é mediada pelas tecnologias sociais que, nesse caso específico, escrevem, ou inscrevem, a história na pele da cidade (KERKHOVE, 2009), tendo em vista que, tanto o lúdico quanto o trágico, tanto a crítica quanto a adesão, encontram-se semantizados nos artefatos representados aqui.

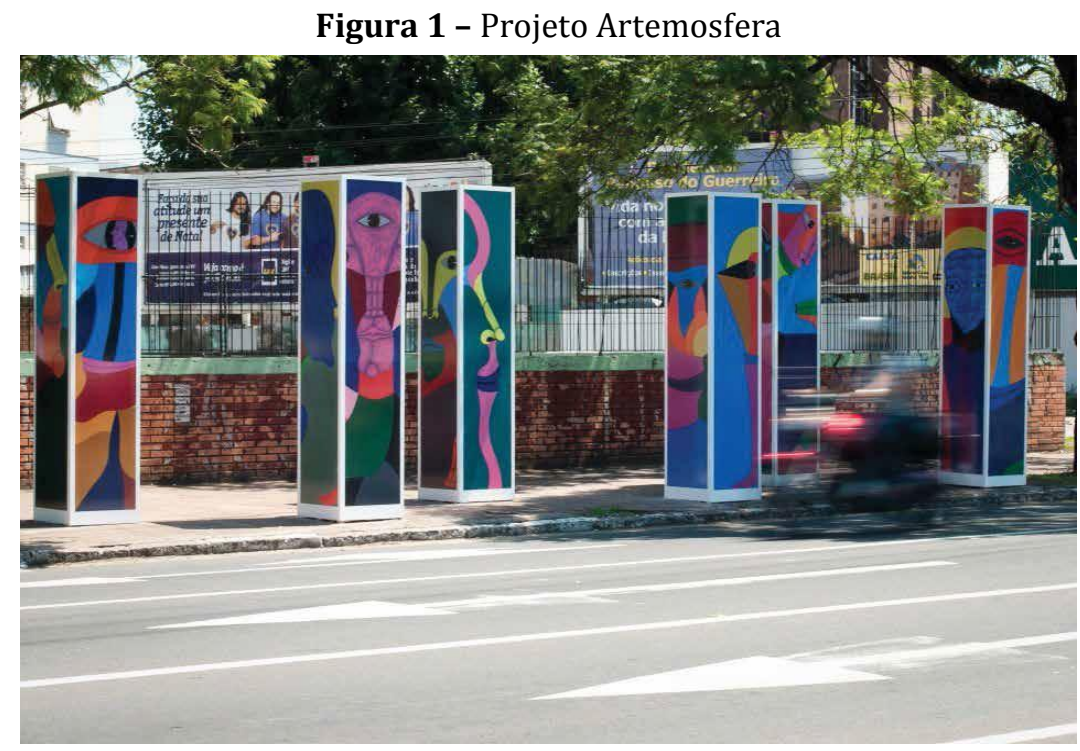

Fonte: Schneider (2013) 
Figura 2 - Imagem da rua

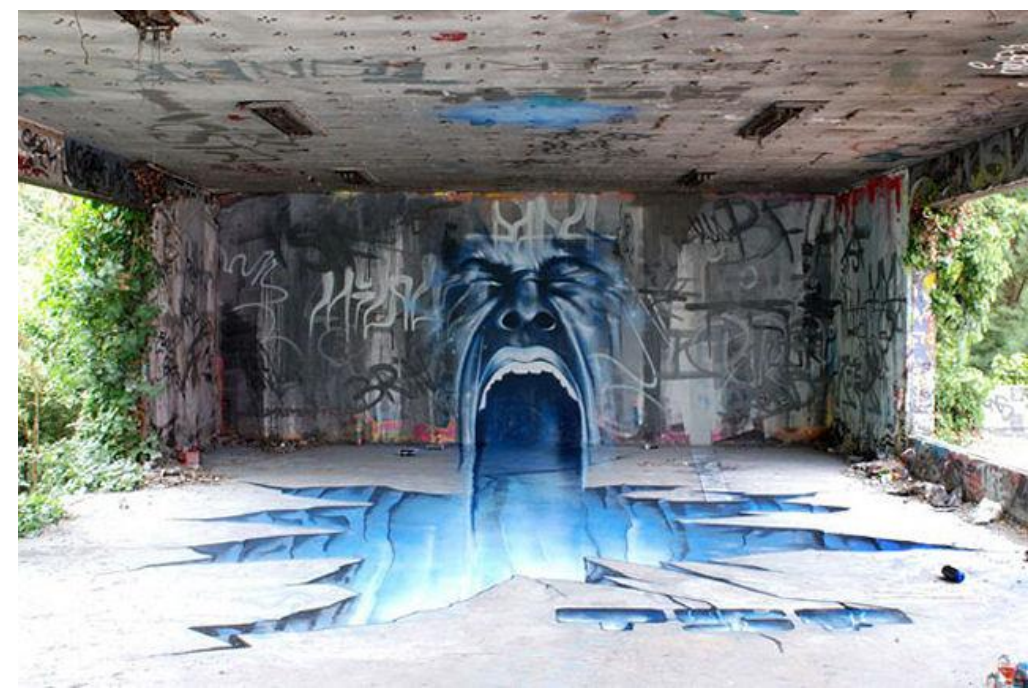

Fonte: Odeith ([201-])

Há uma dupla materialidade: a das cenas, que seriam comparáveis à tela em uma pintura ou ao material de uma escultura; e a das narrativas, que seriam resultantes das cenas em seus entornos e em suas estratégias de visibilidade. Apesar disso, ambas estabelecem uma relação de predicação, pelo que remetem uma a outra, e de complementariedade, pela forma como se articulam entre si. Além disso, expostas às intempéries, têm em seus corpos as marcas da entropia que, por sua vez, também participam da composição da mensagem. São narrativas descritas pela materialidade dos ícones e que produzem leituras indiciais e simbólicas (PEIRCE, 1999). 0 que se quer ressaltar, portanto, é a relevância de cada um desses elementos que integra o todo da mensagem. Seria possível, inclusive, aproximar essa percepção das teorias que consideram os meios como extensão do homem (MCLUHAN, 2002), como prolongamento, neste caso, dos olhos ou dos sensores cognitivos de captura da mensagem. Essas apreensões primárias podem produzir desde o prazer com o texto, até a crítica social e a ironia.

É na definição de simbólico como forma preferida de transações significativas que aparece a figura da metáfora, ou melhor, a sua sequência organizada em alegorias. As narrativas são construções alegóricas articuladas em cenas ou enunciados que, juntos, atualizam uma determinada interpretação de réplica ou de simulacro. Nesse sentido, trabalha-se uma fonte de interpretação histórica que assume o caráter do documento, como se fora uma "testemunha". 
Esse caráter testemunhal aponta para as mudanças que aqueles museus e bibliotecas que não desapareceram do cenário sociocultural vêm sofrendo, transformando-se em palcos onde os artefatos históricos têm suas histórias reescritas. Desta forma, esses prédios se tornam, também, suportes significantes que compõem a narrativa urbana, integrados aos sentidos que se quer produzir.

\section{Retórica visual}

As narrativas que constituem o acervo selecionado para análise são construções alegóricas articuladas em cenas ou enunciados que, juntos, atualizam uma dada disposição física dos materiais que estimula uma determinada interpretação de réplica ou de simulacro. As narrativas expressas por metáforas e alegorias correspondem à uma dada retórica visual que se pretende analisar.

\subsection{Narrativa: metáforas e alegorias}

O novo ciclo de geração da arte urbana permite a performance e o reconhecimento de artistas e do público como agentes de processos de produção de passeios culturais. Na concepção de cenários para uma prática cultural, o espaço de arte urbana atua como ruptura, espetáculo e experiência democrática, ressignificando o popular e o cotidiano dos lugares. Diferentemente de um outdoor publicitário ou de uma placa indicativa utilitária, a peça feita de totens (Figura 1) foi exposta nas calçadas de uma avenida da cidade de Porto Alegre, inaugurando um novo olhar, uma nova fruição, e provocando o desejo de parar, descer do carro, ou, senão, de ficar imóvel na contemplação do elemento novo na paisagem prosaica da calçada. É essa combinação de espaço urbano, especificamente de trânsito, que compõe o suporte híbrido que se expressa no todo da composição. 0 grafite, por sua vez, apresenta outra temporalidade, devido ao seu aspecto fixo, gravado nos muros, paredes ou em outros suportes similares (Figura 2), que permite que possa apenas ser apagado ou sobreposto por outra imagem. Estão expostas também alterações, agregações ou supressões, que esse tipo de arte contemporânea parece autorizar, ou seja, abarca-se a possibilidade de intervenção na narrativa, mesmo quando não se tratando de uma obra coletiva. Talvez essa seja uma tendência na composição dos textos/obras em que se produz, através da interação, o acolhimento de diversas subjetivações. 
Nesse sentido, o que se compreende é que essas realidades simbólicas se apresentam como verdadeiros acontecimentos, como operações significativas sempre em aberto, a propor processos dinâmicos de ressignificação. Na perspectiva da inovação que se produz por mudanças de significação (VERGANTI, 2009), o que vem acontecendo nas ruas pode ser considerado a materialização de uma nova ordem de pragmatismo e, também, da prática de uma nova língua, corporificando diversas formas de inovação. Essa nova língua, assim como os demais sistemas como ela estruturados, pede uma nova gramática que inscreva o sujeito (GOFFMAN, 1975) no discurso, sujeito esse que opera, com unidades e categorias de significação, na composição sempre inaugural das metáforas. As alegorias visuais são resultado desse encadeamento figurativo.

Os textos, sínteses de artefatos e suportes constituem-se, assim, pela inscrição do sujeito nos discursos e pela capacidade estruturante dos núcleos sêmicos que, sintagmaticamente, compõem a narrativa. São os artefatos, considerados encadeamentos cênicos, que organizam narrativas. 0 termo discurso é usado para dar destaque à presença do sujeito na narrativa, um tipo de texto em que os acontecimentos, reais ou não, se respondem uns aos outros e, ainda que o encadeamento temporal oriente sua organização e sua leitura, não se dispõem necessariamente de modo sequencial. As metáforas em seu conjunto alegórico são atos de expressão subjetiva que começam a se estruturar em unidades menores, tanto em frases elementares quanto complexas. Nesse sistema, é um jogo de relações que faz a ligação entre elas. Foram escolhidas, para orientar este estudo, temáticas e práticas contemporâneas que representam uma forma de vida sustentável que destaca a presença da natureza no espaço urbano. A matriz narrativa trabalha: (a) o elemento lúdico, existente em todas as pessoas, em todas as idades e em suas diversas formas; e (b) o elemento de crítica social, que se expressa nas visualidades do grafite e das instalações urbanas, ironizando ou provocando reflexões através da retórica visual.

\subsection{Narrativa: relações e categorias}

Na perspectiva de explorar o universo semântico latente, a pergunta que se faz é a de como descrever as relações que subjazem às leituras aqui propostas. As metodologias disponíveis na literatura são várias, mas a escolha recaiu sobre as propostas, aqui simplificadas, veiculadas pela semiótica francesa. A partir do enquadramento geral dessas formulações, as relações propostas para cada termo são trabalhadas a partir dos princípios da conjunção e disjunção, compreendidos como dialogia entre o separável e o inseparável. A estru- 
tura elementar da significação (GREIMAS, 1973) compreende os signos que resultam da organização dos semas, unidades mínimas de significação. Na estrutura elementar da significação, esses semas organizam o eixo semântico e a articulação sêmica. Se o eixo semântico está na ordem das relações sêmicas (semas), esses se organizam em categorias de cuja relação resultam as articulações. As relações distintivas que as estatuem são, por sua vez, classificadas como nímicas, que se dão no eixo semântico, e como táticas, que se dão entre categorias sêmicas. As relações nímicas - sinonímica ou antonímica - são horizontais, sintagmáticas, e ocorrem no nível do eixo semântico; as hiperonímicas, ou hiponímicas, são verticais, paradigmáticas; já as relações táticas ocorrem entre as categorias sêmicas, ou seja, num segundo nível metalinguístico, em movimentos das partes para a totalidade (hipotáticas) ou da totalidade para as partes (hiperotáticas).

A escolha deste modelo como organização dos sentidos possíveis não pretende esgotar o potencial significativo da narrativa textual visual. Embora o modelo proponha diferentes unidades em progressão, ou seja, das unidades mínimas simples às unidades complexas, não se atribuiu pertinência semiótica à análise dos semas. Apesar disso, o princípio original da organização em nódulos de diferenças e semelhanças não é desprezado em nenhuma das etapas das operações de conjunção e disjunção organicamente compreendidas. Apenas acolhem-se algumas das leituras possíveis, dentre tantas resultantes de outros olhares e de outras culturas.

Portanto, a passagem das categorias para seu preenchimento semântico possibilita que se diga que a abrangência das categorias ultrapassa um dado artefato, isto é, que elas possuem um caráter heurístico na pesquisa qualitativa a que se propõem interpretar. A pluralidade dos textos abre um leque de polissemias, reconhecidas, de modo ordenado ou interconectado, pelas isotopias propostas. É o que aqui se faz: os artefatos que seguem podem expressar parte do potencial significante a eles atribuído. Para fins de leitura, as notações em itálico, entre barras simples ou duplas, remetem a diferenças entre eixos e categorias, e indicando diferentes níveis de análise, foram usadas para informar sobre a organização isotópica primária. 


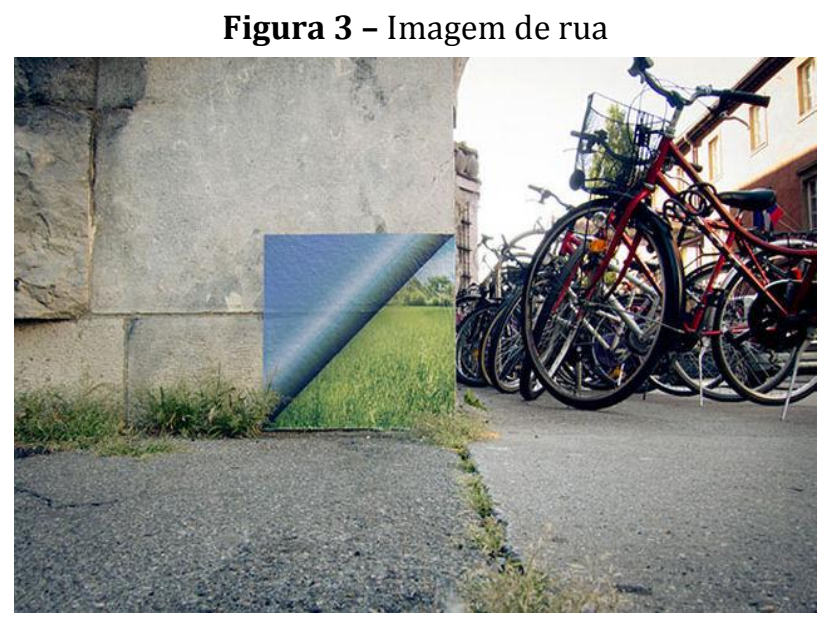

Fonte: Techno World (2012)

É o que se expressa na metáfora antitética (Figura 3) em que /denúncia/ e /solução/ articulam o //APELO//, semantizado em /CONVIVÊNCIA/. Esses enunciados compõem o caráter conativo da mensagem, articulado pela redundância metalinguística entre a gramaviva e a grama-colagem; a natureza que espia os transeuntes e o diálogo que ela estabelece com as bicicletas. Tratam-se de categorias sêmicas nímicas e táticas, sintagmáticas e, ao mesmo tempo, que aparecem em um segundo nível metalinguístico que expressa o movimento paradigmático das partes para a totalidade. Os actantes principais, o muro e a natureza, pedem passagem. Em paralelo, outras significações podem ser atualizadas, pois a dobra que se apresenta no canto inferior direito da imagem marca a conexão visual entre a grama-papel e a grama-viva, além de simbolizar o pedido de atenção para o que se quer dizer: lembre-se que o mineral (morte) deve abrir espaço para o vegetal (vida) e, porque não, a ele sobrepor-se em nome da preservação, não apenas do meio ambiente, mas da própria vida humana sobre a terra. 
Figura 4 - A árvore na rua

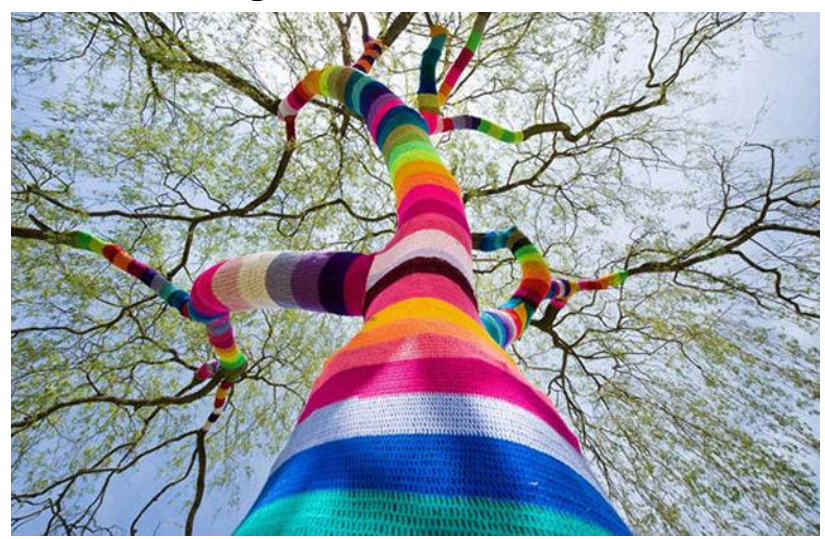

Fonte: Techno World (2012)

Já na Figura 4, acima, é a metáfora lírica que articula a natureza e o homem: ela, representada pela árvore frondosa; ele, pelo artefato artesanal que simboliza culturalmente o cuidado, o aconchego, a proteção, o amor. É //NATUREZA// a unir /comunhão/ e /cuidado/, articulados pelo /AFETO/, como semantização. Nesse caso, as relações sêmicas são sinonímicas, horizontais e sintagmáticas e o movimento categorial é hipotático, portanto, paradigmático. Entre os actantes principais, a árvore e a roupa, é o homem que, na roupa, se metaforiza, no suporte da árvore como real representado. Em síntese, o homem doa generosamente, tal qual a natureza o faz. Expressão do imaginário como ícones isolados, esses dois elementos estão simbolicamente articulados. Outra narrativa que pode ainda ser proposta é a da árvore antropomorfizada, ícone do corpo que veste a roupa (polissemia troncocorpo e tronco-vegetal), membros superiores (braços-corpo e braço-galhos) e cabeça (cabeça-cabelos e copa-folhas), relações possibilitadas pelas analogias formais significantes percebidas na retórica visual narrativa. A posição vertical do artefato, que se abre para o céu, marca o sentido do movimento de baixo para cima, índice de positividade e que simboliza o diálogo com o universo para além do solo, rumo ao céu. Na retórica religiosa cristã, seria uma mensagem ao divino, ao eterno, ao verdadeiro, à liberdade plena só em Deus alcançada. Quiçá, poderia ser a metáfora de um hino à liberdade e à plenitude.

É preciso que se diga que a mesma flexibilidade com que é tratada a arte/artefatos aparece também na simbolização de menor coerção moral. São liberalidades contemporâneas que atingem todas as esferas da sociedade e do conhecimento. Esse modo de ser encontra, na mobilidade e na multifuncionalidade, maior liberdade de organização; um reflexo de disponibilidades menos restritivas no cenário das relações sociais. Há uma autorização implícita para propor, refutar e criar. Parafraseando Baudrillard (2012), se diria: libertam-se os 
objetos significantes e libertam-se os usuários; decompõem-se as imagens urbanas e desestruturam-se as ordens estabelecidas. De certa forma, um dado tom kitsch (MOLES, 1972) está presente nos materiais que compõem o acervo deste trabalho. Estão presentes alguns princípios como inadequação, cumulação, sinestesia e falseamento, que enlaçam a relação ambígua entre arte e kitsch. Em muitos sentidos, essa estética é também uma arte de viver, e talvez seja nesse domínio que encontre sua maior autenticidade, sendo ela criada por e para o homem médio, o chamado cidadão da prosperidade, no duplo papel de criador e criatura.

Figura 5 - Imagem da rua; asfalto e água

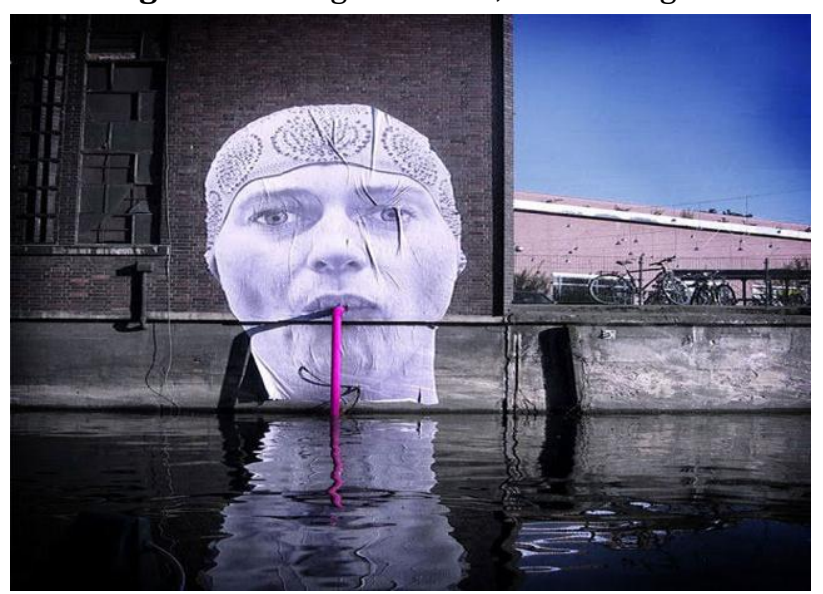

Fonte: Techno World (2012)

A Figura 5 atualiza o processo antonímico simbólico a partir da situação trivial e cotidiana que é tomar água. Ao fazer referência à fonte principal da manutenção da vida, a narrativa coloca o homem, representado sobre o muro, diante do dilema que contrapõe a vida ( artefatos) à natureza, conferindo-lhe o protagonismo simbólico de doador de vida. A ironia que se apresenta articula duas sequências: uma, organizada pela //CIDADE// na qual a ingestão da /água/ que nutre o /homem/, nutre também todos os seres vivos, nas normas até então reconhecidas neste planeta. Semantiza-se em /VIDA/, nessa perspectiva de análise. Seria possível, ainda, trabalhar a metáfora antitética da /NÃO-VIDA/ (categoria não explorada), em que a água que percorre as ruas da cidade está corrompida pela poluição. 0 homem urbano a toma, mas ela mais agride do que nutre. Assim, a água desdobra-se tanto em fonte de vida quanto em fonte de morte.

Aí reside a ironia que produz a contundente crítica social: o homem sorve, em doses homeopáticas, o germe da morte e da degradação. No que se refere a ironia da comunicação (JEUDY, 2001), esse jogo linguageiro opera simbolicamente sobre as memórias coletivas, 
produzindo nas pessoas o sentido de pertencimento. Talvez seja por isso mesmo que a crítica, irônica ou mordaz, longe de esvaziar o sentido dos artefatos, os reforça, pelo cruzamento sêmico entre a seriedade dos acontecimentos e seu contraponto.

Para além dessas percepções, há outros elementos de potencial significativo. Como exemplo, há a representação metonímica do homem pela sua cabeça, imagem que constrói outra metáfora propositiva, uma vez que o desenvolvimento humano ao longo dos tempos traz a expectativa de que se utilize a racionalidade e o conhecimento para a preservação de sua humanidade. Essa premissa, portanto, implica a necessidade de preservação do meio ambiente em seus recursos naturais, para a preservação da vida do homem e das demais espécies. Como tal, o homem pode ser destinado a tornar-se guardião de uma natureza que, sem interferências humanas, mantém um processo de autorregulação sistêmica, transformadora, mas natural. Em função disso, mais importante seria o papel desse guardião.

Por outro lado, não são, também, sem sentido os elementos cor e touca com que o homem tem sua cabeça coberta. Essa visualização é complementada pelo aspecto das águas. A totalidade dos elementos está enquadrada em outra antítese metafórica: a vida da cidade (a cor) no quadro superior direito; o perigo que a ronda a metrópole (o preto-cinza), cujas cores marcam a estratégia da mensagem. Há um grande operador nesse universo: o homem, cujo livre-arbítrio o torna diretamente responsável pelo caos ao qual a natureza é submetida.

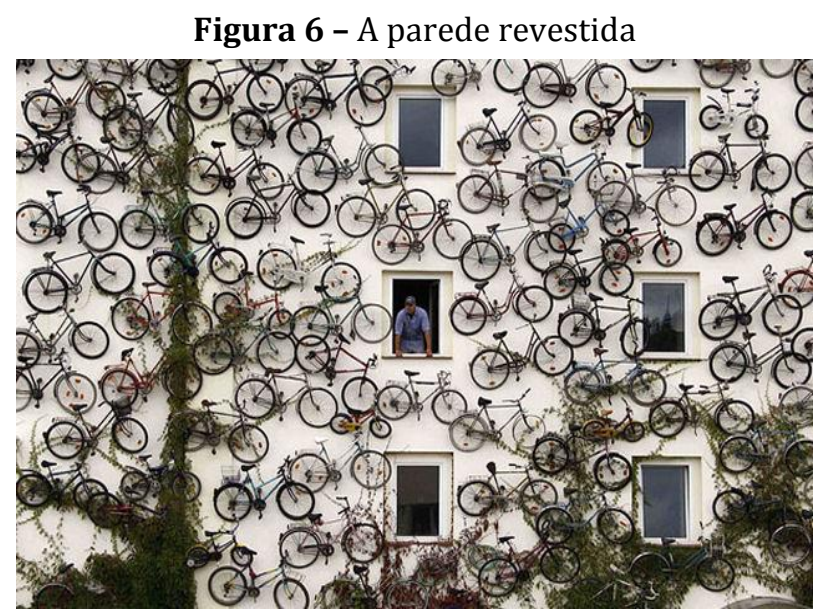

Fonte: Techno World (2012)

A Figura 6, por fim, apresenta uma mensagem de otimismo e redenção. 0 homem contemporâneo deve mover-se na cidade; o progresso trouxe o motor e a rapidez, e com ele o sedentarismo e a exploração dos combustíveis, predominantemente fósseis, que são finitos; 
a cidade colocou os homens entre paredes e muros duros e cerceantes; então, o que fazer? É o //CONVITE// que é feito pelo homem que se debruça sobre a janela, para olhar de dentro para fora. Também pode, neste caso, ser lido como um hino, como uma apologia ao bem viver. A mensagem metafórica e sintagmaticamente relaciona a mobilidade urbana ao meio de locomoção movido à força física. Simbolicamente, as categorias /mobilidade/ e /saúde (saudabilidade) / apontam para um presente-futuro, que coloca o homem como principal actante da ressignficação da cultura. A categoria //CONVITE// semantiza-se em /DIALOGIA/. Nessa narrativa, a coexistência de semas de natureza não é insignificante, estando expressas nos arbustos verdes que sobem pelas paredes, e as diversas janelas, vãos abertos, que na mesma superfície se voltam para o mundo exterior e completam a narrativa. Por outro lado, também é significativo o fato de as bicicletas estarem coladas nas paredes, formando uma síntese sinérgica. Tecnologias, ambas, paredes e bicicletas, formam uma só pele urbana. Reconhecida a potencialidade do texto, significa dizer que outras leituras e articulações poderiam ser propostas. No caso da primeira escolha aqui feita, há um sintagma em que relações antonímicas, ou disjuntivas, separam prédio, bicicletas e natureza; no entanto, esse sintagma se reinterpreta na narrativa como relações sinonímicas horizontais, em categorias hipotáticas, de natureza paradigmática na origem, que contam uma história.

Sob forma de discurso, os signos icônicos descrevem-se e indiciam as teses que podem, ou querem, comunicar. As criações artísticas e culturais produzem reações transformadoras no seu interior e, a partir dele, para fora de si. É uma revolta formal de modos de expressão artística que, não aceitando passivamente as propostas da sociedade, propõe novos modos de expressão, a fim de recusar, subverter, mudar e inovar (GOLDMANN, 1972).

\subsection{O quadrado semiótico}

Nessa mesma perspectiva teórica, Greimas (1973) apresenta um modelo de análise, chamado quadrado lógico ou semiótico, que organiza diagramas explicitadores de um conjunto de relações, qualquer que seja ele, por princípios de contrariedade, contradição e complementaridade. Propõem-se dois níveis de análise, ambos metalinguísticos, para o enquadramento das categorias sêmicas trabalhadas na leitura dos artefatos.

O quadrado semiótico é a expressão visual das relações possíveis em um dado universo semântico; que atualizam, simultaneamente, estabilidade reguladora e dinamismo criativo, ambas as realidades que possibilitam trabalhar com estruturas estruturantes. As significações atribuíveis a uma estrutura significante prevêem as seguintes relações: a de (a) 
/contrariedade/, a de (b) /contradição/ e a de (c) /complementariedade/. No primeiro nível metalinguístico, a função /contrariedade/ trabalha a oposição entre afirmação e negação de um termo como contrário, mas não como contraditório; a /contradição/ define um termo em presença e em ausência; e a /complementariedade/ nomeia as relações de complementação que os elementos contratam entre si. Em termos gerais, as operações consideram a linha da /continuidade/ como termo fundador, a que corresponde o seu contrário, /descontinuidade/, o seu complementar, /não descontinuidade/, e o seu contraditório, /não-continuidade/. A linha de /continuidade/ remete ao fluxo encadeado de funções, de caráter regular e constante, que são da ordem da estabilidade; já a /descontinuidade/ semantiza rupturas, interrupções, intervalos ou suspensões, embora mantendo a possibilidade de recuperação do estado da relação de origem. Essas relações podem operar tanto em um primeiro quanto em um segundo nível de metalinguagem. Para fins de análise, chamar-se o primeiro nível de metalinguagem de lógico-narrativo, e o segundo, de lógico-metanarrativo. Entre os enunciados trabalhados, outras relações lógicas podem ser propostas, conforme as intenções de análise. A ressignificação do quadrado lógico/semiótico amplia o potencial operacional do modelo, e esse, por sua vez, amplia, como um todo, a capacidade heurística da interpretação.

O quadrado semiótico assim define as relações:

Figura 7 - Quadrado semiótico

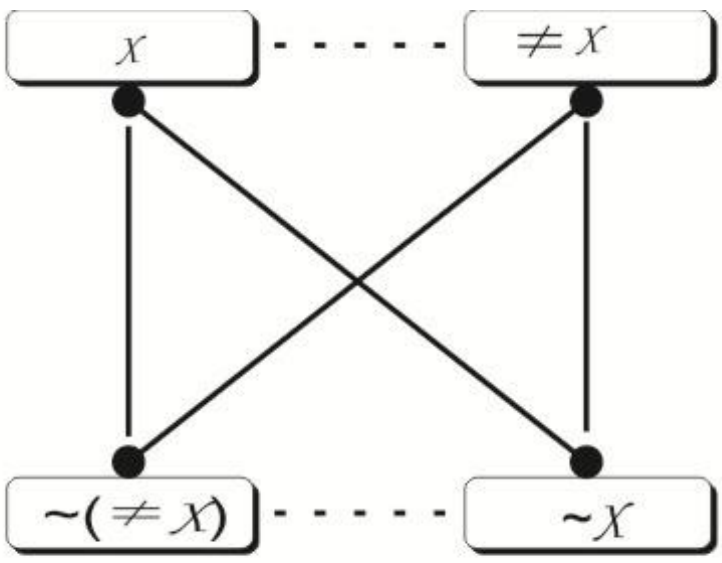

Símbolos

$\mathrm{x}$ : Termo de origem: presença

: Não presença

₹: Diferente, mas não contrário

Relações

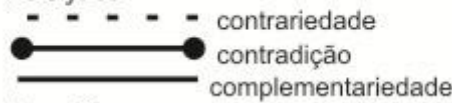

Equações:

$x R \neq x$
$\sim(\neq x) R \sim x$$\Rightarrow$ Contrariedade

$x \mathrm{R} \sim \mathrm{x}$
$\neq \mathrm{x} R \sim(\neq \mathrm{x})$$\Leftrightarrow$ Contradição

$\neq x R \sim X$

$x R \sim(\neq x)$

$\Rightarrow$ Comlpementariedade

Fonte: A autora. 
Complementarmente à Figura 7, as chaves das relações externas ao quadrado semiótico acima, presentes nos modelos logo a seguir, comportam os símbolos $\longmapsto$ para continuidade, e $\perp$ para descontinuidade. Todas essas relações lógicas serão preenchidas temática e estrategicamente, sendo inspiradas, explicitamente ou não, nos eixos e categorias trabalhados no item 3.2 - Narrativa: relações e categorias.

Figura 8 - Quadrado semiótico: relações lógico-narrativas (temas) 1ํㅗ sequência - A DENÚNCIA

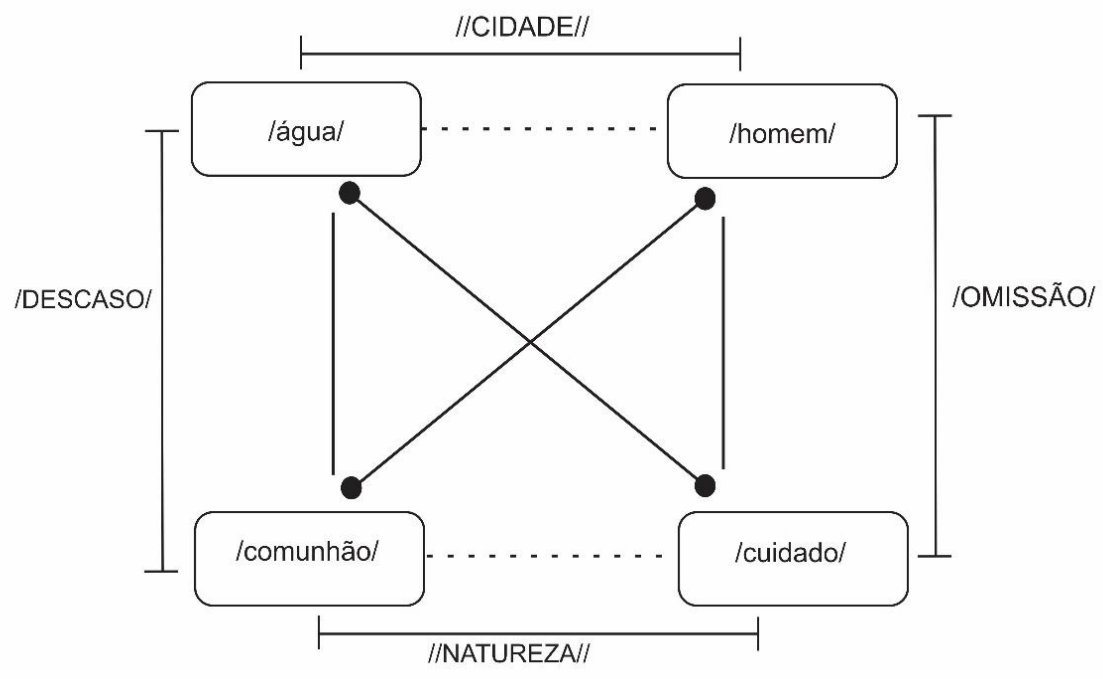

Fonte: a autora.

Figura 9 - Quadrado semiótico: relações lógico-narrativas (temas) 2aㅗ sequência - A PROPOSIÇÃO

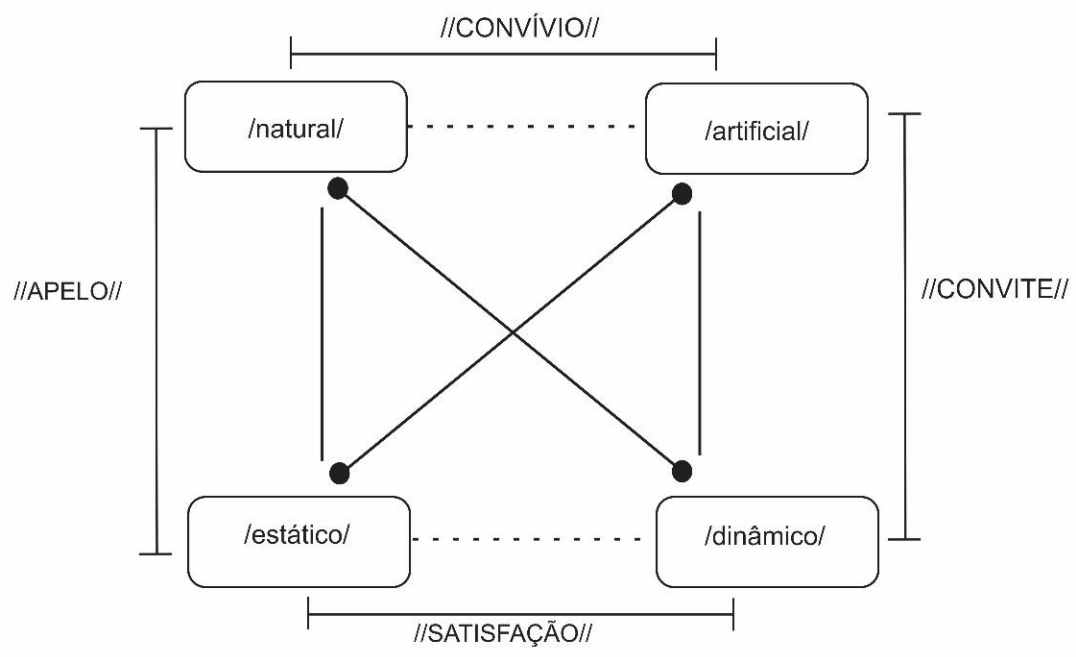

Fonte: a autora. 
Figura 10 - Quadrado semiótico: relações lógico-metanarrativas (estratégias) O DIÁLOGO

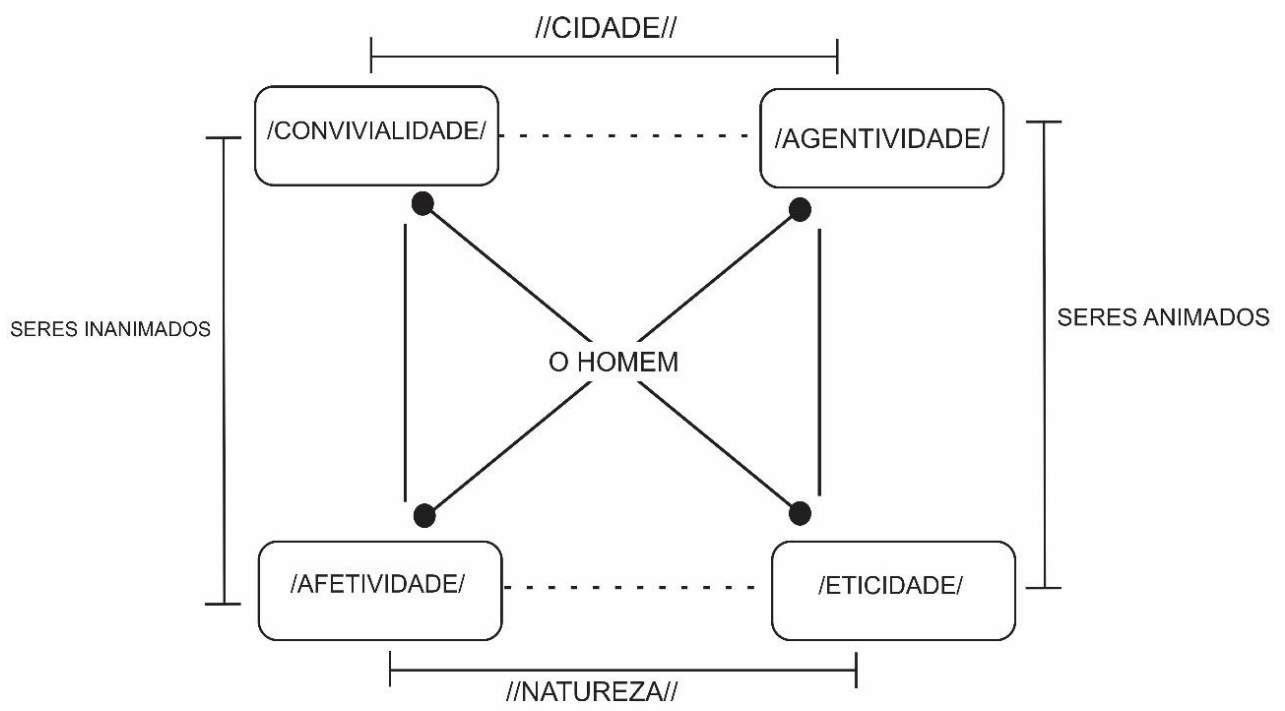

Fonte: A autora.

Esse conjunto de relações narrativas e metanarrativas, identificado a partir da lógica dos enunciados (e presente nos diagramas acima), tem como substrato a dialogia, que, em si, constitui um processo interativo. Seu potencial interpretativo e, portanto, comunicacional, materializa-se no universo semântico no qual o sujeito se torna presente e, também, agente do ato interpretativo de espaços, como no caso dos materiais selecionados aqui, compostos por artefatos comunicacionais. Há duas implicações decorrentes dessa compreensão: (a) uma, implícita nos efeitos de sentido, é a interação comunicacional, sem a qual não haveria conexões interpretativas; e (b) outra, explícita, corresponde aos efeitos de sentido, na reconhecida necessidade de comunicar percepções, processos ou invenções.

Para desenvolver esse tema, convocamos as elaborações de Jakobson (2001) a respeito dos termos e relações que sustentam o processo de comunicação, em uma visão já não aristotélica, mas sim ampliada pelas teorias da linguagem mais atuais. Não nos deteremos em detalhes sobre a importante obra desenvolvida por esse linguista, em vez disso, retomaremos seu esquema de elementos envolvidos no processo de comunicação, que, conectados, produzem atos bem-sucedidos de diálogo. Como as linguagens são fatos fundadores da cultura, quando produzem efeitos, indicam uma cadeia bem-sucedida de elementos em interação. Vê-se, portanto, o potencial do termo "interação", que abarca desde um sentido primário de conexão (pôr em conexão qualquer x com qualquer y) até os efeitos semânticos e pragmáticos na produção de sentidos secundários, complexos ou complementares. 
Segundo o autor acima citado, seis elementos podem ser identificados no processo de comunicação, de cuja conexão depende sua ocorrência. Deve-se destacar que não se trata de avaliar os resultados que poderiam decorrer de um processo bem-sucedido, mas sim as condições para a sua produção. São eles: Fonte, Emissor, Mensagem, Receptor, Destinatário, Código, Contexto e Canal. Esses elementos apresentam-se sempre em fluxo (poderia se dizer, também, em conexão), pois definem-se recíproca e reflexivamente. Para que a mensagem (M) circule, o canal (Ca) precisa estar funcionando. 0 contexto (Cn) e o código (Cd) resultam também dessa operação: o primeiro fica indicado pela $\mathrm{M}$; e o $\mathrm{Cd}$ depende de acordo prévio, tácito ou não. Como atores "vivos" (sendo actantes todos os termos do processo), alternam-se fonte/emissor (F/E) e destinatário/receptor (D/R), preenchidos, conforme o caso, por pessoas ou por máquinas. 0 importante é que os processos interativos comunicacionais testam a eficácia das conexões, levando às necessárias redundâncias que previnem o ruído na comunicação.

Nessa mesma proposta, Jakobson (2001) apresenta as chamadas funções da linguagem (perspectiva funcionalista), diferentes conforme o termo dominante na cadeia, mas sempre em inter-relação nos atos de linguagem. Na perspectiva deste artigo, destacam-se algumas funções em especial: a função poética, que orienta a produção artística; a função referencial, representada pelo contexto urbano público; os múltiplos canais que viabilizam a conexão fática; e a função metalingüística, que aparece nas interpretações e, portanto, encontra-se reelaborada tanto pela linguagem verbal quanto na articulação com a linguagem visual.

Em síntese, a sociedade contemporânea encontra na comunicação o principal aliado para a geração e difusão de valores e de grandes narrativas. Potencializada pelas redes digitais, amplia-se o espectro de difusão e consolidação de uma ordem de inteligência, que tem em sua base as lógicas do compartilhamento e da ressignificação consoantes as condições culturais e tecnológicas. É a ressignificação resultante das experimentações em laboratórios e da solidariedade entre os saberes que poderá estimular projetos inovadores para a arte e a comunicação.

Resultam desse painel de culturas mediadas pelas tecnologias, as representações simbólicas nas práticas sociais, as comunidades de interpretantes como sujeitos promotores da inovação e as mediações tecnológicas como agentes da interação. Assim, as gramáticas dos símbolos, dos discursos colaborativos e das estratégias comunicativas constituiriam o acervo dessas representações simbólicas. Enfim, destaque-se o caráter sincrético das linguagens 
contemporâneas na produção dos símbolos; as ações das comunidades na ressemantização dos espaços urbanos; e o papel das tecnologias da informação e da comunicação nesses processos.

\section{Considerações finais}

A arte como instância mediadora e instauradora de novas sensações e percepções tende a agenciar, desse contexto, a movimentação dos sentidos, ora por rupturas, ora por afirmações, movimentos indicados como de continuidade e de descontinuidade. Os cortes produzidos no tecido coletivo, do mais sutil e imaterial ao mais sólido, sejam implícitos ou explícitos, manifestam um dado modo de significar que é também o modo de estar no mundo. Transitórios ou duradouros, os artefatos encontram suporte no tecido urbano.

Os roteiros da cidade fazem as pessoas circularem pelas rotas traçadas, mas não conseguem impedir desvios ou descobertas que transgridam os caminhos indicados. Na transgressão e na reversão, alicerçam-se os movimentos de continuidade e descontinuidade. A cidade metaforiza-se em corpo, as ruas, em veias/artérias, e os homens são como o sangue que as rega de vida, material e simbólica. Nossa participação no imaginário social está intimamente relacionada com o poder de representação e de mutação das metáforas. Trabalhar metáforas é trabalhar hibridismos que mesclam atitudes, mentalidades, valores e simbolizações de artefatos e práticas. A escolha de representação por metáforas amplia as condições de harmonização das formas de expressão dos homens em todos os ângulos de sua atuação na sociedade, sejam eles, entre outros, no campo do esporte, da religião, das festividades ou das artes (BURKE, 2003).

Neste trabalho são também metaforizados os cenários que, por analogia, compreendem as ruas em seus traçados e a disposição física dos equipamentos ou artefatos, por fim, todo esse conjunto escrito nos espaços, nas paredes, nos postes, nas fachadas dos prédios ou na natureza; suportes e artefatos que atravessam o espaço urbano em diferentes direções e cruzamentos, percorrido pelos actantes que ali constroem suas narrativas.

Esta experiência é contrária ao enfraquecimento do eu ( sujeito do discurso), portanto em resposta à cultura da série, uma vez que destaca a produção das subjetividades. A arte não apenas reflete, mas interage e transforma as forças imanentes e transcendentes no conjunto de relações entre indivíduos e sociedade. É o homem que aparece como principal ordenador dos sentidos. É ele o sujeito das temáticas e estratégias que se inscrevem nas ruas da cidade, e no caso dos artefatos analisados neste trabalho: as temáticas do natural e do 
artificial; do estático e do dinâmico; da denúncia e da proposição; do convite e do apelo; do descaso e da omissão; do convívio e da afetividade; e do diálogo e da satisfação.

\section{Referências}

BARTHES, Roland. 0 prazer do texto. 4. ed. São Paulo: Cultrix, 2008.

BAUDRILLARD, Jean. 0 sistema dos objetos. São Paulo: Perspectiva, 2012.

BURKE, Peter. Hibridismo cultural. São Leopoldo: Unisinos, 2003.

FONTANILLE, Jacques. Significação e visualidades. Porto Alegre: Sulina, 2005.

GOFFMAN, Irving. A representação do eu na vida cotidiana. Petrópolis: Vozes, 1975.

GOLDMANN, Lucien. A criação cultural na sociedade moderna. São Paulo: Difusão Europeia, 1972.

GREIMAS, Algirdas Julien. Semântica estrutural. São Paulo: Cultrix, 1973.

JAKOBSON, Roman. Linguística e comunicação. 22. ed. São Paulo: Cultrix, 2001.

JEUDY, Henri-Pierre. A ironia da comunicação. Porto Alegre: Sulina, 2001.

MCLUHAN, Marshall. Os meios de comunicação como extensões do homem. 12. ed. São Paulo: Cultrix, 2002.

MOLES, Abraham et al. Semiologia dos objetos. Petrópolis: Vozes, 1972.

ODEITH, Sergio. Screaming ghost. Anamorphic Graffiti. Lisboa, [201-]. Disponível em: <http://www.odeith.com/anamorphic/>. Acesso em: 1 nov. 2013.

PEIRCE, Charles Sanders. Semiótica. 3. ed. São Paulo: Perspectiva, 1999.

TECHNO WORLD. The best example of amazing street art. [S.l.], 2012.

TODOROV, Tzvetan. As estruturas narrativas. 4. ed. São Paulo: Perspectiva, 2003.

SCHNEIDER, Tárlis. [Artemosfera]. Porto Alegre, 2013. 1 fotografia. Projeto Artemosfera, obra de Moacyr Kruchin e Britto Velho. Disponível em:

<http://www.artemosferapoa.com.br/>. Acesso em: 1 nov. 2013.

VERGANTI, Roberto. Design driven innovation: changing the rules of competition by radically innovating what things mean. Boston: Harvard Business Press, 2009. 


\title{
Art on the streets: a strategy reframing and of communication interaction
}

\begin{abstract}
The paper investigates the effects that visual rhetoric has in the composition of metaphors/urban allegories by producing symbolic meanings and through the connections of communication brought by urban technologies. These artifacts are so present in our daily lives that they have become prostheses into the body of the city. Thematic and contemporary practices were chosen that representate forms of nature in urban space and therefore produce a dialogue with culture in the form of narratives. The narrative matrix works with: (a) the playful element, present in different manifestations; and (b) with the social critical element, present in the narrative arguments of the texts in question. The theme of the development complies with the parameters the theories of language, the understanding of semiosis and communication interaction. The objective is to identify and understand how senses respond to the objects and the ways which interaction takes place, both mediated in complex semiosis by urban devices.
\end{abstract}

\section{Keywords}

Artifacts. Cities. Environments. Narratives. Metaphors.

Recebido em 16/09/2015

Aceito em 10/12/2015 